\title{
Filozofia systemu zarządzania środowiskiem wg PN-EN ISO 14001: 1998
}

\section{Wprowadzenie}

Pierwsze programy mające na celu wypracowanie strategii ekologicznego zarządzania środowiskiem miały miejsce już w latach 60-siątych $X X$ wieku. Początkowo ograniczały się do naprawy skutków katastrof ekologicznych i nadmiernego eksploatowania środowiska poprzez przemysł i górnictwo. Na przełomie lat sześćdziesiątych i siedemdziesiątych rozpoczęła się ewolucja świadomości ekologicznej w kierunku działań zapobiegawczych. Na Konferencji w Sztokholmie w roku 1972 zapoczątkowano prace mające na celu poszukiwanie rozwiązań prawnych i ekonomicznych mających na celu ochronę środowiska, a w szczególności ochronę wód i powietrza. Zaowocowało to kilkoma dokumentami prawnymi o charakterze globalnym, najważniejsze $z$ nich, to:

- Protokół Montrealski z 1986 r.; dotyczył ograniczenia stosowania substancji niszczących warstwę ozonową. ${ }^{1}$

- Raport Brudtland "Nasza wspólna przyszłość" z 1987 r.; podkreśla istotę wzrostu roli społeczeństwa $\mathrm{w}$ rozwiązywaniu problemów związanych $z$ ekologią. W raporcie tym wprowadzono pojęcie koncepcji zrównoważonego rozwoju (ekorozwoju). ${ }^{2}$

- Konwencja o ruchu przygranicznym niebezpiecznych odpadów i ich składowania, Bazylea 1989.3

- Deklaracja z Bergen z 1990 r.; podkreślająca, że do realizacji zasad zrównoważonego rozwoju niezbędne są działanie i współpraca jednostek pozarządowych.

Instytut Ekologii i Bioetyki UKSW w Warszawie.

1 H. SKRZYPEK, Normy ISO 14000 jako narzędzie ochrony środowiska w strategii przedsiębiorstw'a, w: Świadomość i edukacja ekologiczna, J. M. Dołęga, J. Sandner (red.), Warszawa 1998, s. 167.

2 Por. Nasza wspólna przyszlość. Raport Światowej Komisji do spraw Środowiska i Rozwoju (World Commission on Environment and Development), Warszawa 1991, s. 44.

3 B. SITEK, Antropologiczne podstaw'y ochrony środow'iska w' prawie w'spólnotow'ym, w: Prawa czlowieka w' państwie ekologicznym, R. Sobański (red.), Warszawa 1998, s. 64. 
- Dyrektywa Rady Wspólnot Europejskich o swobodnym dostępie do informacji w sferze środowiska z 1990 r. (Dyrektywa EWG 313/90); zapewnia wolny dostęp do informacji o środowisku będących w posiadaniu władz rządowych i samorządowych (lokalnych). ${ }^{4}$

- Konwencja o ocenach oddziaływania na środowisko w kontekście transgranicznym podpisaną przez Espoo w 1991 r.

- Deklaracja z Rio w sprawie środowiska i rozwoju z 1992 r.

- Agenda 21 z 1992 r.; zawiera plan działań zmierzający do wprowadzenia w życia zrównoważonego rozwoju.

- Konwencja w sprawie transgranicznych skutków awarii przemysłowych, Helsinki $1992 \mathrm{r}$.

- Konwencja o ochronie i użytkowaniu cieków wodnych i jezior międzynarodowych, helsinki 1992 r.

- Konwencja o odpowiedzialności cywilnej za szkody wyrządzone działalnością niebezpieczną dla środowiska, Lugano 1993 r.

- Program działań na rzecz ochrony środowiska dla Europy Środkowej i Wschodniej, Lucerna 1993 r.

- Konwencja o dostępie do informacji, udziale społeczeństwa w podejmowaniu decyzji oraz dostępie do sprawiedliwości w sprawach dotyczących środowiska, Aarhus 1998 r. ${ }^{5}$

By spełnić wymagania prezentowane $\mathrm{w} w / \mathrm{w}$ dokumentach na poziomie przedsiębiorstwa lub jednostki terytorialnej należało zarządzanie oprzeć na rozbudowanej świadomości ekologicznej preferującej otoczenie miejsca zamieszkania i pracy przyjazne dla człowieka i środowiska. Spowodowało to powstanie systemów zarządzania środowiskowego.

\section{Podstawy filozoficzne systemu zarządzania środowiskowego}

\section{1. Koncepcja zrównoważonego rozwoju (sustainable development)}

\section{1. 1. Definicje ekorozwoju}

Koncepcja zrównoważonego rozwoju utrwalona w świadomości od czasu opublikowanego w 1987 r., przez ONZ raportu "Nasza wspólna przyszłość", oparta jest na uznaniu procesów ograniczających swobodny wzrost gospodarczy, powodujący regres, a inicjowany procesami wzrostu. Polega to na uświadomieniu faktu, że człowiek w swym rozwoju ograniczony jest możliwościami środowiska oraz że próby przekroczenia

4 Por. Dyrektywa Rady Wspólnoty Europejskiej z 7 czerwca 1990 r. o swobodnym dostępie do informacji w sferze środowiska, w: Ochrona środowiska.

5 S. BACZULIS, Konwencja z Aarhus a uspotecznienie ochrony środowiska w Polsce, w: Polityka ekologiczna III Rzeczpospolitej, A. Papuziński (red.), Bydgoszcz 2000, s. 324-327. 
tych możliwości grożą regresem i zagładą części przyrody a nawet życia na Ziemi. Według niej:

Truaty rozwoój to rozwoj, który zaspokaja potrzeby obecne, nie pozbawiając przyszłych pokoleń możlizości zaspokajania ich potrzeb. ${ }^{6}$

Koncepcja ta jest obecna w Polskiej Konstytucji:

Zrównoważony rozwój - to taki rozwój społeczno-gospodarczy, w którym w celu równoważenia szans dostępu do środowiska poszczególnych społeczeństw lub ich obywateli - zarówno współczesnego, jak i przyszłych pokoleń - następuje proces integrowania działań politycznych, gospodarczych i społecznych z zachowaniem równowagi przyrodniczej oraz trwałości podstawowych procesów przyrodniczych."

Ekorozwój jest zatem humanizacją rozwoju gospodarczego, politycznego i społecznego zapewniającą godziwe warunki do życia obywatelom, ich dzieciom i wnukom, a przy tym taki rozwój ,który nie zmienia się w zagładę, czy jakikolwiek regres. ${ }^{7}$

Dariusz Kiełczewski podaje następującą definicję:

Ekorozzoój jest to spotecznie pożądany, uzasadniony ekonomicznie i dopuszczalny ekologicznie rozwoój gospodarczy. Jest to, więc taki model rozzoju, w którym wszelkie procesy zachodzace wezonatrz systemu spotecznego sq zharmonizozvane z procesami zachodzacymi w systemie przyrodniczym. Dzicki temu miçdzy obiema sferami utrzymuje się taki stan równowagi, który zapezwia truatość istnienia obu systemózo.

Franciszek Piontek definiuje:

Zrózunoważony rozwój to zapewnienie truałej poprawy jakości życia wospótczesnych $i$ przysztych pokolen, co wiqże sic $z$ trwatym $i$ integralnym powiazaniem ekologii z poprawq jakości życia i środowviska życia człowieka. ${ }^{9}$

\section{1. 2. Cele i prawa ekorozwoju}

Trwały rozwój powinien realizować następujące cele;

- Sprawiedliwe podejście do wszystkich ludzi na Ziemi poprzez niwelowanie różnic między zamożnością ludzi, walkę z analfabetyzmem, chorobami, zapewnienie ochrony życia i zdrowia wszystkim ludziom na Zie$\mathrm{mi}$, zaspokojenie potrzeb intelektualnych, położenie kresu wojnom, nienawiści, zniewolenia, dominacji międzynarodowej oraz ochronę różnorodności kulturowej społeczeństw;

Nasza wspólna przysztość. Raport Światowej Komisji do spraw Środowiska i Rozwoju (World Commission on Environment and Development), Warszawa 1991, s. 67.

7 R. POCHYLUK, P. GRUDOWSKI, J. SZYMAŃSKI, Zasady w'drażania systemu zarzqdzania środowiskowego zgodnego z wymogami ISO 14001, Gdański 1999, s. 19-23.

8 D. KIEECZEWSKI, Motywy i koncepcje ochrony środow iska, w: Ochrona środowiska przyrodniczego, G. Dobrzański, B. Dobrzańska, D. Kiełczewski, Bialystok 1997, s. 201-216.

9 B. PIONTEK, F. PIONTEK, W. PIONTEK, Ekorozwój i narzędzia jego realizacji, Białystok 1997, s. 10-11; B. PIONTEK, Koncepcja rozwoju zrów'now'ażonego i trúatego polski, Warszawa 2002, s. 14-27. 
- Dbałość o potrzeby przyszłych pokoleń poprzez oszczędne gospodarowanie zasobami przyrody zachowujące jej znaczną część na przyszłość, utrzymanie dynamicznej równowagi środowiska przyrodniczego i recylkulację zasobów.

- Dbałość o potrzeby istot pozaludzkich poprzez utrzymanie równowagi ekologicznej, zabezpieczenie godziwego przetrwania gatunków, podporządkowanie działań wzorcom i prawom przyrody na obszarach nie zdominowanych przez czlowieka, zabezpieczenie przed zniszczeniem przez człowieka.

W działaniach gospodarczych ekorozwój wymaga przestrzegania następujących praw:

- Prawo regionu - potrzeby rozwojowe muszą być dostosowane do regionalnych i lokalnych uwarunkowań przyrodniczych i woli społeczeństw lokalnych.

- Prawo skali i jakości - zakaz eksploatowania i zanieczyszczania środowiska ponad ekologicznie uwarunkowanym normom.

- Prawo celu - uwarunkowania przyrodnicze muszą wyznaczać kierunek rozwoju. ${ }^{10}$

\section{1. 3. Zasady ekorozwoju}

II Polityka Ekologiczna Państwa z 2000 r. podaje, iż wiodącą zasada polityki ekologicznej naszego państwa jest zasada zrównoważonego rozwoju. Ta zasada przedkłada się na następujące zasady konkretyzujące:

1) zasada przezorności

a. zasada wysokiego poziomu ochrony środowiska

2) zasada integracji polityki ekologicznej z politykami sektorowymi

3) zasada równego dostępu do środowiska przyrodniczego:

a. kategoria sprawiedliwości międzypokoleniowej

b. kategoria sprawiedliwości międzyregionalnej i międzygrupowej

c. kategoria równoważenia szans pomiędzy człowiekiem a przyrodą Powyższe zasady skutkować powinny symulowaniem procesów:

A. rozszerzania i umacniania możliwości odtwarzania się zasobów odnawialnych i renaturalizacji zdegradowanych ekosystemów;

B. racjonalnego korzystania z zasobów nieodnawialnych i dążenia do ich zastępowania dostępnymi substancjami;

C. stopniowego eliminowania $\mathrm{z}$ użytkowania substancji niebezpiecznych i toksycznych;

D. ograniczenia skali uciążliwości działalności gospodarczej dla środowiska i nie przekraczania granic jego odporności;

10 Tamże, s. 213-214; S. KOZŁOWSKI, Ekorozwoój. Wyzwanie XXI wieku, Warszawa 2000, s. $105-133$ 
E. zwiększenia bezpieczeństwa prowadzenia procesów z udziałem materiałów niebezpiecznych i ograniczenia występowania oraz skutków zagrożeń środowiska o charakterze nadzwyczajnym;

F. stałej ochrony i odtwarzania - w możliwym zakresie - różnorodności biologicznej na poziomie krajobrazowym, ekosystemowym, gatunkowym i genowym;

G. tworzenie podmiotom gospodarczym warunków do uczciwej konkurencji $w$ sferze dostępu do ograniczonych zasobów środowiska i możliwości odprowadzania zanieczyszczeń;

H. usprawnienia procesów podejmowania decyzji dotyczących środowiska, zwlaszcza na szczeblu lokalnym, w tym stymulowania udziału społecznego w tych procesach;

I. dążenia do zapewnienia poczucia bezpieczeństwa ekologicznego poszczególnym jednostkom i grupom społecznym (tworzenia warunków sprzyjających zdrowiu fizycznemu, psychicznemu i społecznemu, w tym poprzez kultywowanie więzi lokalnych).

4) zasada regionalizacji:

a. rozszerzenie uprawnień dla samorządów

b. regionalizowanie ogólnokrajowych narzędzi polityki ekologicznej w odniesieniu do obszarów:

- obszarów silnie przekształconych i zdegradowanych lub zagrożonych degradacją;

- obszarów o wysokich walorach przyrodniczych (z przewaga funkcji ochronnych, naukowych i rekreacyjnych oraz znaczącą roląleśnictwa i ekologicznego rolnictwa);

- obszarów pośrednich (z przewaga intensywnego rolnictwa i umiarkowanie rozwijanego przemysłu, przede wszystkim przetwórczego);

c. skoordynowanie polityki regionalnej $\mathrm{z}$ regionalnymi ekosystemami w Europie

5) zasada uspołecznienia polityki ekologicznej

6) zasada "zanieczyszczających połaci" (złożenie pełnej odpowiedzialności, w tym materialnej, za skutki zanieczyszczenia i stwarzania innych zagrożeń dla środowiska na sprawcę, tj. na jednostki użytkujące zasoby środowiska)

a. realizacja przedsięwzięć ochronnych (zmiany technologii, wykorzystywanych nośników energii i surowców oraz budowa urządzeń oczyszczających) będzie na przedsiębiorstwach wymuszana środkami prawnymi w postaci zakazów, prawnie obowiązujących norm emisyjnych, wymogów licencyjnych itp., w takim zakresie, by uzyskać bezpieczny stan środowiska wynikający $z$ prawa międzynarodowego bądź wewnętrznego;

b. zagrożenia dla środowiska $\mathrm{z}$ tytułu wprowadzania do obrotu $\mathrm{i}$ użytkowania substancji i wytworów niebezpiecznych dla środowi- 
ska (zagrażających zdrowiu i przyrodzie na poziomie ekosystemowym, gatunkowym i genetycznym) będą minimalizowane narzędziami prawnymi (zakazy produkcji i użytkowania bądź ograniczenia w użytkowaniu) oraz mechanizmami ekonomicznymi (opłaty produktowe, depozyty ekologiczne, ubezpieczenia ekologiczne)

c. nadal będą stosowane opłaty za korzystanie ze środowiska, w takim stopniu, w jakim będzie to konieczne dla uzyskania założonych i ekonomicznych efektów.

7) zasada prewencji (przeciwdziałanie negatywnym skutkom dla środowiska na etapie planowania i realizacji przedsięwzięcia), preferowane będą działania usytuowane w następującym porządku hierarchicznym:

a. zapobieganie powstawaniu zanieczyszczeń i innych uciążliwości, tj. działanie na rzecz przebudowy modelu produkcji i konsumpcji w kierunku zmniejszania presji na środowisko - w szczególności poprzez stosowanie tzw. Najlepszych dostępnych technik (BAT)

b. recykling, tj. zamykanie obiegu materiałów i surowców, odzysk energii, wody i surowców ze ścieków i odpadów oraz gospodarcze wykorzystanie odpadów zamiast składowania

c. zintegrowane podejście do ograniczenia i likwidacji zanieczyszczeń i zagrożeń, zgodne z zaleceniami Dyrektywy Rady 96/61/WE w sprawie zintegrowanego zapobiegania zanieczyszczeniom i kontroli (tzw. Dyrektywa IPPC)

d.wprowadzenie pośrodowiskowych systemów zarządzania procesami produkcji in usługami, polegające na systematycznej identyfikacji, a następnie konsekwentnej realizacji celów środowiskowych prowadzących do ograniczania oddziaływań na środowisko i zużywania jego zasobów proporcjonalnie do wielkości produkcji, zgodnie $\mathrm{z}$ ogólnoświatowymi i europejskimi wymaganiami $\mathrm{w}$ tym zakresie, wyrażonymi m. In. W standardach ISO 14000 i EMAS, programach czystszej produkcji i Responsible Care, itp.

8) zasada stosowania najlepszych dostępnych technik (BAT)

9) zasada subsydiarności (stopniowe przekazywanie części kompetencji i uprawnień decyzyjnych dotyczących ochrony środowiska na właściwy szczebel regionalny lub lokalny, tak, aby każdy problem był rozwiązywany na najniższym szczeblu, na którym może zostać skutecznie i efektywnie rozwiązany)

10) zasada klauzul zabezpieczających (umożliwienie państwom członkowskim stosowanie $\mathrm{w}$ uzasadnionych przypadkach ostrzejszych środków w porównaniu $\mathrm{z}$ wymaganiami wspólnotowego prawa ekologicznego)

11) zasada skuteczności ekologicznej i efektywności ekonomicznej. ${ }^{11}$

11 II Polityka Ekologiczna Państwa z 13 czerwca 2000 r., Warszawa 2000, s. 8-11.; Por. Nowa Polityka Ekologiczna Państwa - zatożenia, w: Ochrona środowiska spoteczno - przyrodniczego w filozofii i teologii, J. M. Dolęga, J. W. Czartoszewski, A. Skowroński (red.), Warszawa 2001 , s. $557-586$. 


\section{1. 4. Zarządzanie ekologiczne}

Realizacja programu zrównoważonego rozwoju wymaga perspektywicznej strategii działania odnoszącej się do podstawowych mechanizmów gospodarki człowieka na globie ziemskim.

\begin{tabular}{|c|c|c|}
\hline Lp. & Postulat & Proponowana realizacja \\
\hline 1. & Zasoby naturalne odnawialne & $\begin{array}{l}\text { Korzystanie z zasobów odnawial- } \\
\text { nych (takich jak lasy, ziemia wyko- } \\
\text { rzystywana rolniczo czy zasoby ryb) } \\
\text { należy tak kształtować, aby stopień } \\
\text { wykorzystania nie przekroczył stop- } \\
\text { nia regeneracji }\end{array}$ \\
\hline 2. & $\begin{array}{l}\text { Zdolność absorpcyjna ekosyste- } \\
\text { mów }\end{array}$ & $\begin{array}{l}\text { Obciążając środowisko odpadami i } \\
\text { spalinami należy dążyć do tego, by } \\
\text { stopień zanieczyszczenia byl mniej- } \\
\text { szy od zdolności absorpcyjnej }\end{array}$ \\
\hline 3. & Ryzyka ekologiczne & $\begin{array}{l}\text { Należy całkowicie unikać takich roz- } \\
\text { wiązań technologicznych o dużym } \\
\text { stopniu ryzyka, które doprowadziły } \\
\text { do naruszenia postulatów zrównowa- } \\
\text { żonego rozwoju lub gdyby skutki tej } \\
\text { awarii nie dawały się nawet przewi- } \\
\text { dzieć }\end{array}$ \\
\hline 4. & Zasoby nieodnawialne & $\begin{array}{l}\text { Korzystanie z nieodnawialnych zaso- } \\
\text { bów może być drogą niezbędnego kom- } \\
\text { promisu dopuszczalne tylko w takim } \\
\text { zakresie, w jakim udaje się tak zwięk- } \\
\text { szyć ogólnogospodarczą wydajność } \\
\text { zasobów (lub zmniejszyć intensyw- } \\
\text { ność pozyskiwania zasobów), że } \\
\text { mimo przyrostu gospodarczego doj- } \\
\text { dzie do bezwzględnego zmniejszania } \\
\text { zużycia nieodnawialnych zasobów } \\
\text { oraz, że będą realizowane inne postu- } \\
\text { laty zrównoważonego rozwoju. Na } \\
\text { plan pierwszy wysuwają się trzy stra- } \\
\text { tegie redukcji zużycia: } \\
\text { a) Zwiększenie ogólnogospodarczej } \\
\text { wydajności zasobów przez strategię } \\
\text { oszczędzania i orientowania się na } \\
\text { to, co najniezbędniejsze. Należy do } \\
\text { tego mniej zasobochłonnego stylu } \\
\text { życia i konsumpcji }\end{array}$ \\
\hline
\end{tabular}




\begin{tabular}{|c|c|c|}
\hline Lp. & Postulat & Proponowana realizacja \\
\hline & & $\begin{array}{l}\text { b) Zwiększenie ogólnogospodarczej } \\
\text { wydajności zasobów poprzez postęp } \\
\text { techniczny i organizacyjny } \\
\text { c) Zastąpienie zasobów nieodnawial- } \\
\text { nych zasobami odnawialnymi tylko } \\
\text { i wyłącznie w takim zakresie, w ja- } \\
\text { kim nie zostaną naruszone inne po- } \\
\text { stulaty zrównoważonego rozwoju. } \\
\text { Znaczy to, że nie moga zostać zagro- } \\
\text { żone równowaga zasobów odnawial- } \\
\text { nych, zdolność absorpcyjna ekosys- } \\
\text { temów i ważne dla życia krajobrazy }\end{array}$ \\
\hline 5. & $\begin{array}{l}\text { Utrzymanie zdrowych biosyste- } \\
\text { mów, podtrzymywanie różnorod- } \\
\text { ności biologicznej i respektowanie } \\
\text { podstawowych zasad naturalnej } \\
\text { ewolucji }\end{array}$ & $\begin{array}{l}\text { Aby ludzie żyli zdrowo, a bogactwa } \\
\text { naturalne można było bez przeszkód } \\
\text { zagospodarować, konieczna jest tro- } \\
\text { ska o utrzymanie zdrowych biosys- } \\
\text { temów. Wymaga to podtrzymywania } \\
\text { biologicznej różnorodności w potrój- } \\
\text { nym sensie: różnorodności ekosyste- } \\
\text { mowej, rodzajowej i genetycznej. Po- } \\
\text { nadto w zdrowych biosystemach } \\
\text { musza przebiegać naturalne procesy } \\
\text { ewolucyjne, zwłaszcza ważna jest re- } \\
\text { latywna powolność zmian }\end{array}$ \\
\hline 6. & $\begin{array}{l}\text { Ochrona krajobrazu kulturowego } \\
\text { istotnego dla wartości życia i god- } \\
\text { ności człowieka }\end{array}$ & $\begin{array}{l}\text { Kształtowaniu przestrzeni życiowej } \\
\text { ludzi musi towarzyszyć idea praw } \\
\text { człowieka. Godność człowieka wyma- } \\
\text { ga wartościowego krajobrazu kultu- } \\
\text { rowego }\end{array}$ \\
\hline
\end{tabular}

Tab. 1. Program zrównoważonego rozwoju wg Minsch, 1995. 


\begin{tabular}{|c|c|c|c|}
\hline Lp. & Zadanie & Ocena sytuacji & Proponowana realizacja \\
\hline 1. & $\begin{array}{l}\text { Ograniczenie energo- } \\
\text { chłonności }\end{array}$ & $\begin{array}{l}\text { W } 1995 \text { r. zużyto } \\
\text { zasobów nieodnawial- } \\
\text { nych } 9300 \text { Mtoe* } \\
\text { powodując zmiany } \\
\text { klimatyczne, krajobra- } \\
\text { zowe i spoleczne }\end{array}$ & $\begin{array}{l}\text { - Stabilizacja zużycia energii } \\
\text { w krajach wysoko uprzemy- } \\
\text { słowionych; } \\
\text { - Wprowadzenie podatku } \\
\text { od energii; } \\
\text { - Opanowanie nowych, } \\
\text { bezpiecznych źródeł energii } \\
\text { np. słonecznej; }\end{array}$ \\
\hline 2. & $\begin{array}{l}\text { Ograniczenie materia- } \\
\text { tochł̣onności }\end{array}$ & $\begin{array}{l}\text { Przepływ materiałów } \\
\text { powoduje katastrofę } \\
\text { odpadową }\end{array}$ & $\begin{array}{l}\text { - Redukcja wkładu materia- } \\
\text { łowego: } \\
\text { - Podniesienie cen składo- } \\
\text { wania odpadów; } \\
\text { - Zamykanie obiegu } \\
\text { materiałów (recykling) }\end{array}$ \\
\hline 3. & $\begin{array}{l}\text { Oszczędna gospodar- } \\
\text { ka przestrzenią }\end{array}$ & $\begin{array}{l}\text { - Kurczenie się } \\
\text { powierzchni gruntów } \\
\text { rolnych; } \\
\text { - Postępująca dewa- } \\
\text { stacja krajobrazu; }\end{array}$ & $\begin{array}{l}\text { - Ochrona i rekultywacja } \\
\text { terenów rolnych; } \\
\text { - Wyłączenie z użytkowania } \\
\text { wartościowych terenów eko- } \\
\text { logicznych i krajobrazowych; } \\
\text { - Wprowadzenie podatku } \\
\text { od zabudowania gruntu; } \\
\text { - Ustanowienie Funduszu } \\
\text { Odnowy Krajobrazu; }\end{array}$ \\
\hline 4. & $\begin{array}{l}\text { Ograniczenie rozwoju } \\
\text { infrastruktury } \\
\text { komunikacyjnej }\end{array}$ & $\begin{array}{l}\text { Obecne trendy rozwo- } \\
\text { ju infrastruktury } \\
\text { komunikacyjnej } \\
\text { powodują degradację } \\
\text { miast i krajobrazu }\end{array}$ & $\begin{array}{l}\text { - Przyjęcie „wariantu zerowe- } \\
\text { go" w planowaniu sieci } \\
\text { połączeń komunikacyjnych; } \\
\text { - Wprowadzenie założeń } \\
\text { ekoefektywności komunika- } \\
\text { cji publicznej; }\end{array}$ \\
\hline 5. & $\begin{array}{l}\text { Ograniczenie zagro- } \\
\text { żeń przemysłowych }\end{array}$ & $\begin{array}{l}\text { Narastaja zagrożenia } \\
\text { związane z awariami } \\
\text { przemysłowymi }\end{array}$ & $\begin{array}{l}\text { - Przyjęcie zasad: } \\
\text { 1. żadnego pogorszenia } \\
\text { dobrobytu dla przyszłych } \\
\text { pokoleń; } \\
\text { 2. żadnego zaniżania stopnia } \\
\text { ryzyka; } \\
\text { 3. żadnego przeliczania zagro- } \\
\text { żenia na potencjalne korzyści; } \\
\text { - Wprowadzenie obowiąz- } \\
\text { ku ubezpieczenia na wypa- } \\
\text { dek awarii; } \\
\text { - Rozbudowa struktur } \\
\text { ratunkowych i centrów } \\
\text { dowodzenia; }\end{array}$ \\
\hline
\end{tabular}

Tab. 2. Ekologiczne sterowanie wg Minsch, 1995.

*Mtoe - ekwiwalent milionów ton ropy naftowej. 
Program ekologicznego sterowania w służbie ekorozwoju opracowano w Instytucie Gospodarki i Ekologii Szkoły wyższej a St.Gallen. ${ }^{12}$

\section{2. Filozofia kompleksowego zarządzania jakością (Total Quality Management [TQM])}

Norma BS 7850 definiuje kompleksowe zarządzanie jakością TQM jako:

Filozofia zarządzania i praktyka przedsiębiorstwa, zmierzajaca do najefektyzvniejszego wykorzystania szooich zasobów ludzkich i materialnych, by osiagnać zamierzone cele.

Norma PN-ISO 8402: 1996 określa TQM jako:

Sposób zarządzania organizacja, skoncentrowany na jakości, oparty na udziale woszystkich członków organizacji i nakierowvany na osiggniçcie dtugotrwałego sukcesu dzį̧ki zadowoleniu klienta oraz korzyściom dla wszystkich członków organizacji i dla spoteczeństiva.

Naczelnymi zasadami TQM są:

1. Kreowanie świadomości i zaangażowanie wszystkich pracowników, a przede wszystkim kierownictwa na rzecz jakości.

2. Dążenie do ustalenia i zaspokojenia wymagań klienta zewnętrznego i wewnętrznego.

3. Ciagłą poprawę wszelkich działań wg tzw. cyklu Deminga.

4. Każdorazowe wykonywanie zadań dobrze za pierwszym razem i na czas.

5. Zapobieganie problemom, a nie tylko doraźne ich likwidowanie.

6. Zespołowe podejście do rozwiązywania problemów (każdy jest odpowiedzialny za szeroko pojęta jakość), wyodrębnienie grupy liderów.

7. Inwestowanie $w$ rozwój pracowników wg zasady "ludzie są największym kapitałem przedsiębiorstwa, a ich wydajność i jakość pracy zależy od właściwego zarządzania".

W sferze świadomości pracowników i stosunków międzyludzkich na terenie przedsiębiorstwa TQM wprowadza następujące zasady:

1. Powszechny udział i zaangażowanie pracowników.

2. Powszechna zrozumienie realizowanych procesów i zapewnienie technik oraz mierników określających ich skuteczność.

3. Ustalenie odpowiedniej struktury organizacyjnej, by zapewnić efektywny przepływ informacji i możliwość natychmiastowej korekty niezgodności.

4. Przewidywanie, zdefiniowanie i bieżąca obserwacja wymagań odbiorców wewnętrznych i zewnętrznych.

5. Identyfikacja potrzeb szkoleniowych w przedsiębiorstwie oraz prowadzenie szkoleń.

$\overline{12}$ S. KOZŁOWSKI, tamże, s. 131-133. 
System zarządzania środowiskowego wg ISO 14001 w dużym stopniu opiera się na założeniach i zasadach TQM i TQEM (Total Quality Environmental Management) jako na istotnym elemencie, który sprawdził się w systemach zarządzania jakością. ${ }^{13}$

\section{Normy dotyczące systemów zarządzania środowiskiem}

\section{1. BS 7750}

Brytyjska norma BS 7750 została opublikowana w roku 1992 - wersja pierwsza, 1994 - wersja ostatnia. Jej podstawowym celem było stworzenie możliwości dla zbudowania efektywnego systemu zarządzania będącego bazą dla racjonalnych działań na rzecz środowiska. Norma ta nie ustanawiała kryteriów oceny skuteczności działań, lecz wymagała jedynie zgodności $z$ ustawodawstwem dotyczącym ochrony środowiska i zobowiązywała do ciągłej poprawy. ${ }^{14}$

Norma ta pomimo, iż była jedynie normą krajową Wielkiej Brytanii, stosowana była na całym świecie. Po wejściu ISO 14001 w roku 1996 została wycofana. ${ }^{15}$

\section{2. EMAS (Eco-Management and Audit Scheme) ${ }^{16}$}

Regulacja Unii Europejskiej EMAS z 1993 r. ma za zadanie promocję ciągłej poprawy skuteczności działań na rzecz ochrony środowiska w przedsiębiorstwach przemysłowych ma charakter dobrowolny. Jednostka, która podporządkuje się jej musi opracować system zarządzania środowiskowego oraz wydać tzw. Publiczne Oświadczenie środowiskowe, w którym wymagane jest przedstawienie:

1) wykazu osiągnięć na rzecz ochrony środowiska,

2) polityki i celów środowiskowych,

3) programu ich osiągania,

4) terminu opublikowania następnego oświadczenia,

5) nazwiska weryfikatora.

Oświadczenie musi być zweryfikowane przez akredytowanego audiutora. W roku 1999 poszerzono zakres stosowania audiutu. ${ }^{17}$

13 R. POCHYLUK, s. 24-26.

14 H. SKRZYPEK, s. 170.

15 R. POCHYLUK, s. 36-37.

If EMAS - w polskim tłumaczeniu nazywać można jako: Program Eko-Zarządzania i Audytów Wspólnot Europejskich - T. PODGAJNIAK, A. OCIEPA, D. JAŹWIŃSKA, Poradnik

17 przygotow'ujqcy do rejestracji w' systemie EMAS, Warszawa 2003, s. 7.

17 Tamże, s. 37; H. SKRZYPEK, s. 170-171. 
EMAS w swych założeniach i podstawowych zasadach uwzględnia:

1) Dobrowolność

2) Dostępność

3) Jawność danych

4) Okresowość

5) Niezależną weryfikację ${ }^{18}$

W obecnej rzeczywistości po wprowadzeniu Rozporządzenia EMAS Nr 761/2001 z 19 marca 2001 roku system został rozbudowany do rozmiarów większych niż System Zarządzania Środowiskiem według ISO 14001. Stąd możemy zauważyć, że Komisja Europejska dąży do tego, by rejestracja EMAS miała bardziej prestiżowy charakter niż certyfikat ISO $14001 .^{19}$

Ponadto Państwa Członkowskie UE są zobowiązane do stworzenia warunków do prawidłowego rozwoju i funkcjonowania Programu EMAS.20

\section{3. ISO 14001 (International Organization of Standarization)}

Jest jedyną międzynarodową normą przedstawiającą wymagania systemu zarządzania środowiskiem. Została przyjęta przez Europejski Komitet Normalizacyjny (Comite Europeen de Normalisation CEN [European Committee for Standardization]) 21 sierpnia 1996 roku pod nazwą System zarządzania środowiskowego - Specyfikacja i wytyczne stosowania (ISO 14001: 1996) [Environmental management systems - Specification with guidance for use (ISO 14001: 1996)]. W Polsce normę oznaczono symbolem PN-EN ISO 14001: 1998 i ustanowiono przez Polski Komitet Normalizacyjny w dniu 7 września 1998 r. (Uchwała nr 40/98-o). ${ }^{21}$

\section{3. 2. Cechy normy}

Norma ta posiada następujące cechy:

1. Przystosowana jest do ustawodawstwa środowiskowego na całym świecie, umożliwia uwzględnienie wymagań poszczególnych krajów.

2. Może być stosowana przez każda jednostkę organizacyjną, tj. produkcyjną, usługową, handlową, transportową, administracyjną.

3. Poprzez swoje rozwiązania zmierza w kierunku zapobiegania szkodliwym oddziaływaniem na środowisko.

4. Celem jej jest ciągła poprawa działań na rzecz środowiska.

18 T. PODGAJNIAK, tamże, s. 11-12.

19 www.ekoforum.ceti.pl z 14.11.2004 r.

20 T. PODGAJNIAK, tamże, s. 44.

${ }^{21}$ Zestaw norm, Wybór zestawu norm przygotowanych przez Wydawnictwa Normalizacyjne ALFA-WERO 1999. 
5. Ma charakter całkowicie dobrowolny, lecz z chwilą przyjęcia jej przepisy stają się obowiązujące.

6. Opiera się na udokumentowanych i weryfikowalnych procedurach.

7. Kładzie nacisk na zobowiązania ciagłłej poprawy.

8. Wymaga zgodności z obowiązującym ustawodawstwem.

9. Przywiązuje wagę do przepisów i zarządzeń wewnętrznych dotyczących ochrony środowiska.

10. Kładzie nacisk na zapobieganie zanieczyszczeniom we wszystkich możliwych elementach środowiska naturalnego (emisja do powietrza, zrzuty wody, gospodarka odpadami). ${ }^{22}$

\section{3. 3. Wymagania normy}

Wdrożenie normy ISO 14001 wymaga:

1. Określenia polityki środowiskowej przedsiębiorstwa, w której uznano, że zarządzanie środowiskiem to priorytet $w$ jednostce. Polityka ta ma spełniać warunki:

a. kongruencji do charakteru, skali oraz wpływów jej działań, wyrobów lub usług na środowisko;

b. zawierać zobowiązanie do ciągłego doskonalenia oraz zapobiegania zanieczyszczeniom;

c. zawierać zobowiązania do spełnienia odpowiednich wymagań wynikających $\mathrm{z}$ ustawodawstwa i przepisów prawnych dotyczących środowiska oraz innych wymagań, które dotyczą organizacji;

d.stanowiła ramy do ustalenia i przeglądu celów oraz zadań środowiskowych;

e. była udokumentowana, wdrożona i utrzymywana oraz zakomunikowana wszystkim zatrudnionym;

f. była publicznie dostępna.

2. Uwzględnienia w planowaniu:

a. aspektów środowiskowych;

b. wymagań prawnych i innych (mających zastosowanie do aspektów środowiskowych).

c. celów i zadań spójnych z polityką środowiskowa;

d.programów zarządzania środowiskiem.

3. Przestrzegania we wdrażaniu i funkcjonowaniu:

a. odpowiednich struktur personalnych i odpowiedzialności;

b. przeprowadzania szkoleń poprawiających świadomość i kompetencje pracowników wszystkich szczebli;

c. opracowania i utrzymywania wewnętrznego systemu komunikowania się;

d.prowadzenia odpowiedniej dokumentacji systemu zarządzania;

22 H. SKRZYPEK, s. $171-172$. 
e. nadzoru nad dokumentacją;

f. sterowania op0eracyjnego;

g. opracowania i przestrzegania procedur na wypadek awarii i reagowania na awarię:

h. zapewnienia odpowiednich środków;

4. Sprawdzania i działań korygujących:

a. prowadzenia monitoringu i pomiarów;

b. kontroli, a w razie niezgodności prowadzenia działań korygujących;

c. prowadzenia zapisów;

d.poddawania się audiutom;

e. okresowe przeglądy wykonywane przez kierownictwo. ${ }^{23}$

\section{3. 4. Efekty związane $z$ zastosowaniem systemu zarządzania środowiskiem}

Opracowanie i wdrożenie systemu zarządzania środowiskiem jest procesem trudnym i pracochłonnym. Proces ten to inwestycja z dziedziny organizacji i zarządzania, wymaga pokonania wielu przeciwności oraz poprawy świadomości niemal wszystkich pracowników przedsiębiorstwa. Tym nie mniej może przynieść następujące korzyści dla firmy;

1. Zmniejszenie kosztów działalności poprzez:

a. poprawę efektywności bieżących procesów (zmniejszenie zużycia surowców, energii i ilości odpadów oraz odpowiednie utrzymanie maszyn i urządzeń) oraz wdrażanie nowych bardziej efektywnych procesów;

b. projektowanie wyrobów i usług w sposób pozwalający ograniczyć zużycie zasobów naturalnych, bez pogorszenia jakości;

c. odpowiednie zagospodarowanie odpadów (recykling i inne formy gospodarczego wykorzystania odpadów);

d.optymalizację doboru surowców, materiałów, produktów;

e. zwiększenie efektywności wykorzystywanej infrastruktury (obiekty, zaopatrzenie w media);

f. odpowiednie przygotowanie procesów magazynowania, pakowania i transportu;

2. Spełnienie wymogów prawnych:

a. uniknięcie potencjalnych kar pieniężnych;

b. uniknięcie niekorzystnego wizerunku firmy;

3. Przewidywanie przyszłych wymagań prawnych:

a. budowanie prawidłowej świadomości ekologicznej wśród załogi;

b. ewentualna możliwość zdobycia przewagi nad konkurencją;

4. Zmniejszenie ryzyka środowiskowego.

5. Spełnienie wymogów odbiorców.

23. Polska norma PN-EN ISO 14001. 
6. Poprawa relacji ze służbami ochrony środowiska i wizerunku w społeczeństwie.

7. Wzrost zaangażowania pracowników.

8. Możliwość prowadzenia akcji zapobiegawczych, a nie korekcyjnych. ${ }^{24}$

\section{3. 5. Praktyka wdrażania ISO 14001}

Pomimo korzyści płynących z wprowadzenia systemu w przedsiębiorstwie oraz zachęty ze strony władz rządowych zainteresowanie wprowadzeniem systemu zarządzania środowiskiem wg ISO 14001 było początkowo bardzo małe. ${ }^{25} \mathrm{~W}$ naszym kraju w końcu 2001 r. jedynie 400 jednostek posiadało certyfikat. ${ }^{26}$ Spowodowane było to zapewne wieloma barierami, do których można zaliczyć:

1. Słabą kondycją finansową przedsiębiorstw (walka o przetrwanie i brak inwestycji).

2. Skomplikowaną strukturę polityczną samorządów oraz niskim poziomem wykształcenia i świadomości ekologicznej działaczy samorządowych.

3. Niskim poziomem moralności decydentów politycznych i ekonomicznych.

4. Ogólnym brakiem poszanowania wartości w społeczeństwie, w tym i wartości ekologicznych.

5. Niskim stanem świadomości ekologicznej.

6. Brakiem dostrzegania jasnych perspektyw przez ogół społeczeństwa, co prowadzi do apatii i braku kreatywności.

7. Istniejącą możliwością omijania (nie przestrzegania) obowiązującego prawa.

8. Brakiem dbałości o dobro wspólne społeczeństwa.

9. Niewielką ilością sprawdzonych marek firmowych.

10. Brakiem korzyści doraźnych:

a. ulg podatkowych;

b. zniżek w składkach ubezpieczeniowych, itp.

Dopiero perspektywa wejścia Polski do struktur Unii Europejskiej i konieczność konkurowania polskich przedsiębiorstw z przedsiębiorstwami zagranicznymi skłoniło do poprawy wizerunku firmy. Tym niemniej badań sondażowych przeprowadzonych w październiku 2004 r. przez VRG Strategia Kraków i Szwedzka Agencją Rozwoju Przedsiębiorstw w roku 2002 wynika, że najczęstszym źródłem sugestii i nacisków na wprowadzenie działań proekologicznych są: Inspektorzy Ochrony Środowiska, Inspektorzy BHP i organizacja ekologiczne. Mniejszym źródłem nacisku są: pracownicy firmy, związki zawodowe i mieszkańcy okolic. Natomiast najmniejszy wpływ mają: klienci i partnerzy handlowi, lokalne władze oraz doradcy i konsultanci.

24 R. POCHYLUK, s. $15-18$.

25 II Polityka.

26 Agenda 21. 10 lat po Rio, Warszawa, lipiec 2002, s. 176. 
Ponadto z badań powyższych wynika, że najważniejszymi motywacjami podjęcia działań proekologicznych są:

- chęć obniżenia kosztów

- poprawa wizerunku firmy

- możliwość poprawienia pozycji rynkowej

- chęć poprawy stanu środowiska w okolicy (bez motywacji ekonomicznych)

- wzgląd na pracowników (poprawa BHP)

mniejszy wpływ mają:

- przymus prawny wynikający z obowiązujących przepisów

- nacisk lub wymogi stawiane przez klientów lub kontrahentów firmy najmniejszy wpływ mają:

- nacisk ze strony mieszkańców okolicy

- nacisk ze strony władz lokalnych

- nacisk lub wymogi stawiane przez banki lub firmy ubezpieczeniowe. ${ }^{27}$

Po 1 maja 2004 r. w Polsce nastąpiła możliwość certyfikacji obowiązujących w Krajach UE. Pociąga to też wymagania dla naszego kraju obowiązku stworzenia warunków dla korzystnego rozwoju i funkcjonowania Programu EMAS. Zapewne wynikiem tego będzie stopniowe odchodzenie przedsiębiorstw i instytucji od Systemu Zarządzania Środowiskiem według ISO 14001 i przechodzenia do Programu EMAS.

Broniąc się przed marginalizacją Międzynarodowa Organizacja Normalizacyjna (ISO) opublikowała 15 listopada 2004 r. zweryfikowane i poprawione wersje norm ISO 14001:2004 i ISO 14004:2004, które wejdą w życie 15 maja 2005 r. ${ }^{28}$

\title{
Philosophy of environmental management systems according to ISO 14001 in Poland
}

\author{
SUMMARY
}

Author discusses attributes, requirements and effects which was legated by application environmental management systems and presents putting in practice ISO 14001 in Poland. Author considers also philosophical bases of sustainable development idea and philosophy of Total Quality Management [TQM] and British norms BS 7750 .

27 D. Pilis, Przyczyny podejmowania działań prośrodowiskowych przez małe i średnie przedsiębiorstwa w Polsce, Fundacja Partnerstwo dla Środowiska, www.epce.org.pl; 14.11.2004.

28 www.ekoforum.ceti.pl - 22.11.2004. 